Abstracta Iranica Abstracta Iranica

Revue bibliographique pour le domaine irano-aryen

Volume 32-33 | 2013

Comptes rendus des publications de 2009-2010

\title{
Françoise Briquel-Chatonnet, Roberto Bertolino (eds.). Hatra. Site irakien en danger. Patrimoine mondial de l'Unesco
}

Vito Messina

\section{OpenEdition}

1 Journals

\section{Electronic version}

URL: http://journals.openedition.org/abstractairanica/40467

DOI: 10.4000/abstractairanica.40467

ISSN: 1961-960X

Publisher:

CNRS (UMR 7528 Mondes iraniens et indiens), Éditions de l'IFRI

\section{Printed version}

Date of publication: 1 December 2013

ISSN: 0240-8910

\section{Electronic reference}

Vito Messina, «Françoise Briquel-Chatonnet, Roberto Bertolino (eds.). Hatra. Site irakien en danger. Patrimoine mondial de I'Unesco », Abstracta Iranica [Online], Volume 32-33 | 2013, document 145, Online since 01 July 2016, connection on 05 October 2020. URL : http://journals.openedition.org/ abstractairanica/40467 ; DOI : https://doi.org/10.4000/abstractairanica.40467

This text was automatically generated on 5 October 2020 .

Tous droits réservés 


\title{
Françoise Briquel-Chatonnet, Roberto Bertolino (eds.). Hatra. Site irakien en danger. Patrimoine mondial de l'Unesco
}

\author{
Vito Messina
}

\section{REFERENCES}

Françoise Briquel-Chatonnet, Roberto Bertolino (eds.). Hatra. Site irakien en danger. Patrimoine mondial de l'Unesco. Paris, 2009, 96 p., ill. (Dossiers d'Archéologie, 334, juilletaoût).

1 Hatra, the most important archaeological site from the Parthian period known to date, lies in northern Mesopotamia. It was probably the region's main cultural and religious center, a rich city that flourished during the second century AD thanks to its privileged position along trade routes to Syria. The outstanding remains of monumental stone buildings and extraordinary sculptures, most of them discovered during the 20th century, are evidence of a class of wealthy traders and notables. They represent most of the Parthian sculptures recovered till present, and are the main source for the study of the architecture and the arts during the whole Parthian period. For this reason, this site is a treasure chest and world cultural heritage.

2 This publication presents, not just to the scientific community, the progress made in historical and archeological research at this site as well as the problems related to the site. Its scientifically rigorous contributions come from the most distinguished scholars in this field. Readers thus encounter all the major questions about this site's history, cultural context, artistic production and relations with other important centers.

Contents: F. Briquel-Chatonnet, «Pourquoi Hatra?»; M. Gawlikowski, « La ville du soleil, ses seigneurs et ses rois », "Les banquets sous les voûtes »; J. Gaslain, "Le 
monnayage hatréen", "Les rois parthes mentionnés à Hatra "; R. Bertolino, "Les inscriptions la langue et l'écriture", "Les bijoux de Hatra"; T. Kaizer, "Hatra. Temples, dieux et cultes »; M. Mashkour, «Les animaux de Hatra »; L. Dirven, « Hatra, un exemple exceptionnel de l'art parthe »; R. Venco Ricciardi, « Hatra dans le monde parthe »; S. R. Hauser, «Hatra et Assour centres religieux et commerciaux »; J-B. Yon, « Hatra et Palmyre cités de la steppe »; H. B. Al-Aswad, « Un site du patrimoine mondial de l'humanité ».

\section{AUTHORS}

\section{VITO MESSINA}

Università di Torino 